Article

\title{
Lactic Acid Bacteria: Variability Due to Different Pork Breeds, Breeding Systems and Fermented Sausage Production Technology
}

\author{
Giuseppe Comi, Alessia Muzzin, Mirco Corazzin 1 and Lucilla Iacumin * \\ Department of Agriculture, Food, Environmental and Animal Science, University of Udine, via Sondrio 2/A, \\ 33100 Udine, Italy \\ * Correspondence: lucilla.iacumin@uniud.it; Tel.: +39-0432-558126
}

Received: 3 February 2020; Accepted: 10 March 2020; Published: 13 March 2020

check for updates

\begin{abstract}
Changes in the ecology of the various lactic acid bacteria (LAB) species, which are involved in traditional fermented sausages, were investigated in the light of the use of different breeds of pork, each of which was raised in two different environments and processed using two different technologies. The semi-quantitative molecular method was applied in order to understand how the different species alternate over time, as well as their concentration ratios. A significant increase in LAB over the first days of fermentation characterized the trials where the starter culture wasn't added $(\mathrm{T})$, reaching values of $10^{7}-10^{8} \mathrm{cfu} \mathrm{g}^{-1}$. On the other hand, in the trials in which sausages were produced with starter addition, LAB counts had a less significant incremental jump from about $10^{6} \mathrm{cfu}^{-1}$ (concentration of the inoculum) to $10^{8} \mathrm{cfu} \mathrm{g}^{-1}$. Lactobacillus sakei and Lb. curvatus were detected as the prevalent population in all the observed fermentations. Pediococcus pentosaceus, Lb. casei, Leuconostoc mesenteroides, Lactococcus garviae, and Lb. graminis also appeared, but their concentration ratios varied depending on the diverse experimental settings. The results of cluster analysis showed that a plantand breed-specific LAB ecology exists. In addition, it was also observed that the breeding system can influence the presence of certain LAB species.
\end{abstract}

Keywords: lactic acid bacteria; fermented sausages; ecology; breed; breeding system

\section{Introduction}

Traditional fermented sausages are well-known and popular meat products in Italy. In north-eastern Italy, Friuli Venezia Giulia region, traditional fermented sausages are made without the use of microbial starters to preserve the typical characteristics of these products, that are delicate sourness gentle acidity, and elastic consistency. These foodstuffs are made from about $60 \%$ of minced fresh pork meat and $40 \%$ of minced lard mixed with sugar, $\mathrm{NaCl}$, spices and additives (i.e., nitrate, nitrite). Starter cultures are used mainly for large-scale productions [1-3].

The study of microbial ecology during the fermentation of cured meat products began in the 70s [4]. Since then, fifty years of studies have shown that the two groups responsible for the characteristic transformations of these products, regardless of the specific technologies and recipes applied in the different regional cultures, are lactic acid bacteria (LAB) and coagulase-negative catalase-positive cocci (CNCPC) [5-9]. Among them, the species that develop are closely related to the process conditions applied. Specifically, the first parameter of selection is the temperature, which selectively favours the development of some LAB species at the expense of others during the first days of ripening. Sausages subjected to a short ripening using high ripening temperature allow the development of lactobacilli right from the early stages of fermentation and, at the end of ripening, an acidic flavour with slight aroma predominates in salami. Indeed, the $\mathrm{pH}$ decreases due to the transformation of sugars caused by the high concentration of lactobacilli and consequently inhibits the growth of CNCPC [9-12]. 
This phenomenon is directly proportional to the increase in temperature, in fact, the higher the temperature the more the selection pushes towards more acidifying species, with an increasingly more rapid inhibition, not only of the pathogenic and spoiling species, but also of the flavouring ones. On the other hand, sausages with longer maturation and ripening conducted at a lower temperature are characterized by low acidity and higher numbers of CNCPC resulting in a more aromatic product [12]. CNCPC participate in desirable reactions, such as lipolysis and proteolysis, which influence the aroma, besides being makers of the production and stabilization of colour, reducing nitrates in nitrite [13-15].

$\mathrm{LAB}$, therefore, play a primary role in fermented sausages production because they synthesize lactic acid, which causes the lowering of the $\mathrm{pH}$ value and the consequent inhibition of pathogenic bacteria and spoilage microorganisms $[9,15,16]$. Moreover, the acidity accelerates the reduction of the nitrite, and then the process of developing and fixing colour. Finally, LAB release substances, which affect the flavour profile, such as acetic acid, ethanol, acetoin, butanediol, and diacetyl, or having antimicrobial effect, such as bacteriocins [17-19].

Over the last 20 years, LAB ecology has been studied by several authors, using both traditional and molecular microbiological techniques. Among them, polymerase chain reaction (PCR) and Denaturing Gradient Gel Electrophoresis (PCR-DGGE) have been extensively used both as a culture-dependent and a culture-independent method [5,20-24]. High-throughput sequencing (HTS) techniques represent a relatively new approach in the way microbiologists address ecology and diversity in different environments, and consequently also in foods. As explained by Franciosa et al. [25], in HTS, mixed nucleic acid molecules from a complex ecosystem can be sequenced, and therefore can lead to a detailed profile of the microbial populations (identified as operational taxonomic units, OTU) present. In the mid-2000s, HTS technologies became ubiquitous in microbial ecology studies, but limitations remain: a) DNA is a chemically stable molecule, which can be found for a long time after the death of a cell; b) quantification of the genera and/or species is only relatively possible. For these reasons this approach cannot be generally applied, but a reasoned choice of method is needed, in particular when ecological studies are made during a relatively short time, and also important is the detection and identification of species whose counts are $<10^{3} \mathrm{cfu} / \mathrm{g}$.

The previous studies have identified species belonging to Lactobacillus genus as the main ones involved in natural sausage fermentation. The species mainly spotted in this kind of products are Lactobacillus sakei, Lb. curvatus and Lb. plantarum [26].

Species and strain dynamics and counts in fermented meat products, as demonstrated by many authors, vary according to function of process conditions, particularly $\mathrm{NaCl}$ concentration and temperature, which have a direct impact on strain selection, $\mathrm{pH}$, and water activity $\left(\mathrm{A}_{\mathrm{W}}\right)$ [27-31]. Other authors illustrated the roles of plant, meat, and ingredients in the selection of a specific microbiota [32-35].

The role of pork breed and breeding system in influencing LAB ecology during fermented sausages' ripening has been not yet explored. This is a gap that deserves to be investigated, because they could have direct and undirect effects on the microbial ecology of meat products. In fact, several studies showed the relevant presence of species belonging to the genus Lactobacillus in both gut and reproductive tract microbiota of pigs [36-38] and demonstrated that breed affects colonic microbiota and immune status since postnatal period (14-49 days) [36,39]. A possible link between the gut microbiota and feed efficiency in pigs was demonstrated by Tan et al. [38], who discovered that, in Landrace pigs, the high-feed conversion rate pigs had a greater abundance of Lactobacillus and Streptococcus than the low-feed conversion rate pigs, having an evident repercussion on pork meat quality [40]. In parallel, it is now well known that the diet also has a very important influence on the modulation of the intestinal flora, both for humans and for animals, including pigs [41,42]; and the breeding system plays a fundamental role on the type of feeding provided [43]. In the case of the outdoor breeding system, compared to the indoor breeding system, there is a greater variability of nutrients supplied as well as a greater movement of the animals with possible repercussions both in the composition of the intestinal microbiota and on the skin of the animal itself. 
Moreover, the microbiological quality of the meat is strictly dependent on the environmental conditions. The meat of healthy and non-fatigued animals is usually sterile, only the lymphatic ganglia and some organs such as liver and spleen can contain microorganisms. However, microorganisms, especially pathogens and/or opportunists, can invade the muscles when the animal is still alive, before slaughter. The causes for this are various and concern, in particular, weakening or stress before slaughter or primary contamination, which can escape the ante-mortem visit: undiagnosed bacteremia and septicemia can be a vehicle for microorganisms deep in the tissues, and psychological stresses can promote the migration of the same from the intestine. The secondary contaminations during all processing phases, remain those to which the cause of the main contamination is due. In particular, during slaughtering, microorganisms present on/in the animal are transferred to the meat, defining its own microbiota [44-46].

Thus, the core of our study was to investigate LAB species ecology and dynamics under different experimental conditions. In particular, fermented sausages produced in both artisanal and industrial plants with meat from pigs belonging to three different breeds, and breeding in either indoor or outdoor systems, were investigated.

\section{Materials and Methods}

\subsection{Fermented Sausages and Sampling Procedures}

The experimental design was described in Iacumin et al. [7]. In particular, all pigs (male) were raised under the same conditions on a farm in Friuli Venezia Giulia Region. Animals were at the same age and kept on the same diet and breeding conditions, specifically outdoor or indoor. All the trials were conducted at the same time. Pigs were slaughtered in the same abattoir, on the same day. The carcasses were divided into half-carcasses and evenly distributed between the two processing plants, so that each one had half of each animal available. Two local meat factories in northeaster Italy were selected for the study: plant $\mathrm{D}$ (industrial) and plant $\mathrm{T}$ (artisanal). The annual sausage production in the industrial plant was approximately 450-500 tons per year. In contrast, the annual sausage production in the artisanal plant was approximately $35-45$ tons per year. Starter culture (Pediococcus pentosaceus) was used only in the industrial plant. Traditional techniques were used for the production of fermented sausages. The final product was ready for sale after 45-50 (plant D) or 90 (plant T) days. Common ingredients for sausage production included $60 \mathrm{~kg}$ pork meat, $40 \mathrm{~kg}$ lard, $2.5 \mathrm{~kg}$ sodium chloride, 70 g black pepper, and $200 \mathrm{ppm}$ nitrite and nitrate. Sugar was not added for fermentation in plant $\mathrm{T}$, whereas in plant $\mathrm{D}, 1.5 \mathrm{~kg}$ sugar was added. The fermentation mixtures were stuffed into natural casings, and the resulting fresh sausages were $25 \mathrm{~cm}$ long and $5 \mathrm{~cm}$ in diameter. All of the sausages made in plant $\mathrm{D}$ were identical in shape and mass $(1 \mathrm{~kg}$ each), whereas the sausages made in plant T were not identical in shape, and their masses ranged from $0.8 \mathrm{~kg}$ to more than $1 \mathrm{~kg}$ each. Ripening parameters were also different in the two plants. The first stage of ripening consisted of 2 days of drying with relative humidity (RH) of $85 \%$ at $18-20^{\circ} \mathrm{C}$ (plant T) or $22{ }^{\circ} \mathrm{C}$ (plant D). The temperature was then decreased to $14{ }^{\circ} \mathrm{C}$ (plant T) or $12{ }^{\circ} \mathrm{C}$ (plant D) at a rate of $2{ }^{\circ} \mathrm{C}$ per day with RH between $60 \%$ and $90 \%$. Further ripening was then performed for the rest of the period at those temperatures $\left(14{ }^{\circ} \mathrm{C}\right.$ plant $\mathrm{T}, 12{ }^{\circ} \mathrm{C}$ plant $\left.\mathrm{D}\right)$ in storerooms with $65 \%-85 \% \mathrm{RH}$. Plant $\mathrm{D}$ had a more effective system to control the environmental temperature and RH than plant $\mathrm{T}$.

In total, 6 batches of products, in triplicate, were monitored in plant $\mathrm{D}$ (using industrial production technology) as follows: (i) Cinta Senese meat, indoor breeding system (D-CS-I); (ii) Cinta Senese meat, outdoor breeding system (D-CS-O); (iii) Goland meat, indoor breeding system (D-G-I); (iv) Goland meat, outdoor breeding system (D-G-O); (v) Mora Romagnola meat, indoor breeding system (D-MR-I); and (vi) Mora Romagnola meat, outdoor breeding system (D-MR-O). In plant T (using artisanal production technology), only 4 batches, in triplicate, were monitored: (i) Cinta Senese meat, indoor breeding system (T-CS-I); (ii) Cinta Senese meat, outdoor breeding system (T-CS-O); (iii) Goland meat, indoor breeding system (T-G-I); and (iv) Goland meat, outdoor breeding system (T-G-O). 
Every batch of products from each plant was exposed to microbiological analysis. Samplings were performed at $0,2,9,23,30,60$, and 90 days in plant $\mathrm{T}$ and $0,9,30,60$, and 90 days in plant $\mathrm{D}$, and three fermented sausages per batches at each sampling point were used for microbiological analysis. A major number of sampling points was applied in plant $\mathrm{T}$, because the fermentation process was slower than in $\mathrm{D}$ and this required an extension of the monitoring, in particular at the beginning of the fermentation process.

\subsection{Microbial Enumeration and Bulk Cell Collection}

Serial dilutions of each sample in 0.25X Ringer's solution (Oxoid, Milan, Italy) were used to inoculate deMan, Rogosa, Sharpe (MRS agar, Oxoid, Milan, Italy) plates, which are widely used to cultivate LAB. Two series of agar plates were inoculated and incubated at $30^{\circ} \mathrm{C}$ for $48 \mathrm{~h}$ in Jair with AnaeroGen ${ }^{\mathrm{TM}} 3.5 \mathrm{~L}$ kit (Oxoid, Milan, Italy). Portions $(0.1 \mathrm{~mL})$ of appropriate dilutions were spread on plates in triplicate. Colonies were counted, and results were calculated as the means of three determinations. After counting, all plates were used for bulk formation as previously described [23]. In brief, a bulk formation was performed using all plates from the serial dilutions ( -2 to the last). For each dilution, all colonies grown on the plates' surface were suspended in $2 \mathrm{~mL}$ of quarter strength Ringer's solution, harvested with a sterile pipette and frozen at $-20^{\circ} \mathrm{C}$. To minimise the effects of different concentrations, all suspensions were standardised at 1 unit of optical density $(600 \mathrm{~nm})$. Then, $1 \mathrm{~mL}$ of the bulk suspension was used for DNA extraction as described below and subjected to molecular analysis.

\subsection{DNA Extraction from Bulk Cultures}

One milliliter of each bulk suspension was centrifuged at $14,000 \times \mathrm{g}$ for $10 \mathrm{~min}$ at $4{ }^{\circ} \mathrm{C}$ to pellet the cells, and the pellet was subjected to DNA extraction according to Andrighetto et al. [26]. Briefly: the pellet was added to $30 \mu \mathrm{L}$ of Lysozyme $(0.1 \mathrm{~g} / \mathrm{mL}$ Lysozyme, $25 \%$ Sucrose, Sigma-Aldrich, Milan, Italy) and incubated $30 \mathrm{~min}$ at $30^{\circ} \mathrm{C}$ for lysis in a Thermomixer (Thermomixer Confort, Eppendorf, Eppendorf AG, Hamburg, Germany).

\section{4. $P C R$}

Primers P1V1 and P2V1 [24] spanning the V3 region of the 16S rDNA were used in this study. A GC-clamp (5'-CGC CCG CCG CGC CCC GCG CCC GTC CCG CCG CCC CCG CCC G-3) was attached to the $5^{\prime}$ end of primer P1V1 to obtain amplicons to be subjected to DGGE analysis. Amplifications were carried out in a final volume of $25 \mu \mathrm{L}$, containing $1 \mu \mathrm{L}$ (100 ng total) template DNA, $10 \mathrm{mM}$ Tris $\mathrm{HCl}$ ( $\mathrm{pH}$ 8.3), $50 \mathrm{mM} \mathrm{KCl}, 1.5 \mathrm{mM} \mathrm{MgCl} 2,0.2 \mathrm{mM}$ deoxynucleoside triphosphates (dNTPs), $1.25 \mathrm{U}$ Taq polymerase (Invitrogen, Milan, Italy), and $0.2 \mu \mathrm{M}$ each primer, using the thermal cycler DNA Engine DYAD ${ }^{\mathrm{TM}}$ SYSTEM. The amplification cycle included an initial denaturation step at $95^{\circ} \mathrm{C}$ for $5 \mathrm{~min}$, followed by 35 series composed by denaturation, performed at $95^{\circ} \mathrm{C}$ for $1 \mathrm{~min}$, annealing at $45^{\circ} \mathrm{C}$ for $1 \mathrm{~min}$, and extension performed at $72{ }^{\circ} \mathrm{C}$ for $1 \mathrm{~min}$. Finally, an extension cycle, performed at $72{ }^{\circ} \mathrm{C}$ for $7 \mathrm{~min}$, was added. The PCR products were resolved by agarose (Sigma-Aldrich, Milan, Italy) $(2 \% w / v)$ gel electrophoresis at $100 \mathrm{~V}$ for $2 \mathrm{~h}$. In each electrophoresis gel, $3 \mu \mathrm{L}$ of PCR Marker (100 bp) were loaded in the first and in the last well. After running, amplicons were visualized under UV light using the Syngene G: Box Chemi-XX9 (Syngene, Cambridge, United Kindom) and digitally captured by using the software GeneSys version 1.5.7.0 (Syngene, Cambridge, United Kindom).

\subsection{DGGE Analysis}

The DCode universal mutation detection system (Bio-Rad Laboratories S.r.l., Milan, Italy) was used for DGGE analysis. For PCR products obtained with the primers P1V1-GC and P2V1, electrophoresis was performed in a 0.8 -mm-thick polyacrylamide gel $(8 \%$ ( $\mathrm{wt} / \mathrm{vol})$ acrylamide-bisacrylamide (37.5:1)), with a denaturing gradient from $30 \%$ to $50 \%(100 \%$ corresponded to $7 \mathrm{M}$ urea and $40 \%$ (wt/vol) formamide) increasing in the direction of the electrophoretic run. Gels were subjected to a constant 
voltage of $130 \mathrm{~V}$ for $3 \mathrm{~h}$ and $30 \mathrm{~min}$ at $60^{\circ} \mathrm{C}$. After the electrophoresis, gels were stained for $30 \mathrm{~min}$ in 1.25X Tris-acetate-EDTA containing 1X SYBR Green (final concentration; Molecular Probes, Milan, Italy). Pictures of the gels were visualized under UV light using the Syngene G: Box Chemi-XX9 (Syngene, Cambridge, United Kindom) and digitally captured by using the software GeneSys version 1.5.7.0 (Syngene, Cambridge, United Kindom).

A reference pattern was established consisting of amplicons from 4 different bacterial species: Lactobacillus brevis (DSMZ 20054), Lb. casei (DSMZ 20011), Lb. curvatus (DSMZ 6179) and Lb. sakei (DSMZ 6333). By including this standard reference pattern three times on each DGGE gel, resulting DGGE fingerprint band profiles from the different sausages were digitally normalised using Gel Compare 4.1 software Version 4.1 (Applied Maths, Kortrijk, Belgium). Additionally, this reference pattern was used to obtain a preliminary identification of the species. When possible, almost three bands migrating the same position in every single gel were excised and subjected to sequencing and sequence analysis to confirm the preliminary identification and to identify amplicons, which did not correspond to those of the reference strains used. DGGE analyses were performed at least twice.

\subsection{Sequence Analysis of DGGE Bands}

Blocks of polyacrylamide gels containing selected DGGE bands were excised with gel cutting tips. Blocks were then transferred to $100 \mu \mathrm{L}$ sterile water, and the DNA in the bands was left to diffuse overnight at $4{ }^{\circ} \mathrm{C}$. Two microliters of the eluted DNA were used for re-amplification, and PCR products generated with a GC-clamped primer were verified by DGGE. Only products migrating as a single band and in the same position of the control were amplified, as described above, with the primer without the GC clamp. Products were then cloned into the pGEM-T Easy vector (Promega, Milan, Italy) following the manufacturer's instructions. Clones were checked as described above (co-migration with control), and the inserts in appropriate clones were sequenced at a commercial facility (Eurofins, Edersberg, Germany). Sequence comparisons were performed in GenBank using the Blast program version 2.2.18 (https://blast.ncbi.nlm.nih.gov/Blast.cgi) [47].

\subsection{Statistical Analysis}

The statistical tests were performed using R software, vers. 3.4.0 (R core team, 2017, Vienna, Austria). Normality of data distribution and homoscedasticity were tested using Shapiro-Wilk and Levene test, respectively. Data were assessed within the plant. The LAB count in the plant D was analysed with a two-way ANOVA model, with experimental group (batches) and ripening time as factors. Also, the interaction experimental group $\times$ ripening time was considered. For multiple comparisons, the P-values were adjusted using the Holm method, and, when appropriate, the White-corrected P-values [48] were considered. The same model, but with the Scheirer-Ray-Hare test for non-parametric data [49] was used for LAB count in the plant T. Multiple comparisons were performed using Mann-Whitney U test, and the P-values were adjusted using the Holm method.

As a result of the "bulks", the molecular analysis of different fingerprints was performed. Analysis of the patterns and their corresponding dilutions give information about the dominant species occurring and also allows to ascertain the concentration of every single species found in the DGGE profile of the original sample. However, these concentration values are not properly quantitative, they are ordinal value and in statistical analysis they have to be treated as qualitative parameters. For this reason, and to avoid a subjective conversion of the data (from bands in numeric values), a direct cluster analysis from the obtained fingerprints was chosen [7].

The different profiles of each dilution from the same sample were previously joined to get a total sample profile. The profiles of the different times are not treated in a bulk for each sample, but one by one. Pictures of the gels were analysed by using the pattern analysis software package Gel Compare Version 4.1 (Applied Maths, Kortrijk, Belgium). Calculations of similarities in band profiles were based on Pearson (correlation coefficient at 53\%) and Dice (correlation coefficient $60 \%$ ) product-moment correlation coefficients. Dendrograms were obtained via the unweighted pair group method using 
an arithmetic average (UPGMA) clustering algorithm [50]. Two different analyses, using different correlation coefficients (Pearson and Dice), were applied to verify the strength of the results.

\section{Results and Discussion}

\subsection{LAB Counts}

$\mathrm{LAB}$ counts in the different trials and at the different sampling points corresponding to the different fermented sausages production steps were shown in Table 1. Fermentations in plant $T$ were characterised by lower initial LAB counts compared to that in plant $\mathrm{D}$, where P. pentosaceus was added as starter culture $(P<0.01)$.

In plant $T$, the statistical analyses highlighted a significant effect of ripening time $(P<0.01)$, but not of experimental group $(P>0.05)$ on LAB count. Also, the interaction ripening time $\times$ experimental group did not reach a level of significance $(P>0.05)$. LAB count increased from to to t23 $(P<0.05)$, after which counts remained stable till T30 $(P>0.05)$ and then decreased at $90(P<0.05)$, where LAB count was similar to that observed at $99(P>0.05)$. LAB counts slightly decresed at $190(P<0.05)$, where LAB count was similar to that observed at $19(P>0.05)$. At the same time, this difference was not significant compared to LAB count at t60. From a microbiological point of view, this can be explained by the fact that at $\mathrm{t} 90$ the physic-chemical characteristics of the products, such as the combined effect of $\mathrm{pH}$ $(5.32 \pm 0.13$, data not shown), activity water (Aw, $0.925 \pm 0.024$, data not shown) and the absence of sugars led to a progressive slow inactivation of LAB.

In plant $\mathrm{D}, \mathrm{LAB}$ count was affected both by experimental group $(P<0.01)$ and by ripening time $(P<0.01)$. Moreover, also the interaction experimental group $\times$ ripening time was significant $(P<0.01)$. It means that the main effect of a factor can be interpreted only at each level of the other factor. Therefore, in Table 1, the interaction from the perspective of the experimental group is represented in a row, and the interaction from the perspective of ripening time is represented in a column. The first of these shows that LAB count increased from $\mathrm{t} 9$ to $\mathrm{t} 30(P<0.05)$ and, then, remained stable from $\mathrm{t} 30$ to t90 $(P>0.05)$ for the sausages produced with Goland breed, irrespectively of the husbandry system adopted. Furthermore, in the D-MR-I group, LAB count remained stable from t30 to t90 $(P>0.05)$, but, in this group, LAB count started to increase already from t0 to $t 9(P<0.05)$. The D-CS-I and D-MR-O groups showed LAB count that increased from t0 to t9 $(P<0.05)$, but decreased from t60 to $190(P<0.05)$. Conversely, LAB count in D-CS-O decreased from t0 to t9 $(P<0.05)$ and the value recorded at $\mathrm{t} 90$ was similar to that shown at $\mathrm{t} 9(P>0.05)$. Considering the results about the interaction experimental group $\times$ ripening time from the perspective of the ripening time, at $\mathrm{t} 0$, the lowest $\mathrm{LAB}$ count values were observed in sausages produced with the Goland and Cinta Senese breed indoor-housed $(P<0.05)$, conversely, the higher values were recorded in the sausages produced with the same breeds, but with outdoor-housed animals $(P<0.05)$. Lower differences between experimental groups were found in the other ripening times with LAB count that was lower in D-G-I than D-MR-O $(P<0.05)$ at t30, and in D-CS-O than in D-CS-I $(P<0.05)$ and D-MR-O $(P<0.05)$ at t60. Moreover, sausages produced with Cinta Senese breed had lower LAB count that those observed in D-G-O group at 190 $(P<0.05)$. 
Table 1. Mean \pm standard deviation of Lactic acid bacteria (LAB) colony counts, expressed as Log CFU/g, of sausages at different ripening days ( $t$ ) and produced in two plants, industrial (D) and traditional (T) whose meats derived from pigs of three breeds, Goland (G), Cinta Senese (CS), and Mora Romagnola (MR) that were indoor $(\mathrm{I})$ or outdoor $(\mathrm{O})$ housed.

\begin{tabular}{|c|c|c|c|c|c|c|c|}
\hline \multicolumn{8}{|c|}{ Processing Time } \\
\hline & to * & t2 & t9 & t23 & $\mathbf{t} 30$ & $t 60$ & t90 \\
\hline T-G-I & $3.61 \pm 0.21$ & $4.84 \pm 0.03$ & $7.52 \pm 0.13$ & $8.11 \pm 0.09$ & $8.72 \pm 0.05$ & $7.73 \pm 0.14$ & $7.75 \pm 0.01$ \\
\hline T-G-O & $3.99 \pm 0.06$ & $5.52 \pm 0.08$ & $8.52 \pm 0.24$ & $8.95 \pm 0.01$ & $8.12 \pm 0.10$ & $7.96 \pm 0.10$ & $7.95 \pm 0.16$ \\
\hline T-CS-I & $3.53 \pm 0.07$ & $6.69 \pm 0.07$ & $8.00 \pm 0.02$ & $8.56 \pm 0.02$ & $8.54 \pm 0.07$ & $8.87 \pm 0.03$ & $7.78 \pm 0.03$ \\
\hline T-CS-O & $4.50 \pm 0.05$ & $5.07 \pm 0.03$ & $7.93 \pm 0.03$ & $8.72 \pm 0.03$ & $8.42 \pm 0.06$ & $8.20 \pm 0.15$ & $8.29 \pm 0.07$ \\
\hline Mean & $3.91 \pm 0.41^{\alpha}$ & $5.53 \pm 0.74^{\beta}$ & $7.99 \pm 0.39 \gamma$ & $8.62 \pm 0.33^{\delta}$ & $8.45 \pm 0.24^{\delta}$ & $8.19 \pm 0.46^{\gamma \delta}$ & $7.94 \pm 0.23 \gamma$ \\
\hline D-G-I & $6.17 \pm 0.18^{\mathrm{A} \alpha}$ & n.d. & $8.14 \pm 0.24^{\alpha}$ & $8.47 \pm 0.12^{\beta}$ & $8.65 \pm 0.14 \mathrm{~A} \beta$ & $8.45 \pm 0.05^{\mathrm{AB} \beta}$ & $8.54 \pm 0.13^{\mathrm{AB} \beta}$ \\
\hline D-G-O & $6.88 \pm 0.10^{\mathrm{C} \alpha}$ & n.d. & $8.42 \pm 0.30^{\alpha}$ & n.d. & $8.55 \pm 0.14 \mathrm{AB} \beta$ & $8.62 \pm 0.10 \mathrm{AB} \beta$ & $8.58 \pm 0.05^{\text {В } \beta}$ \\
\hline D-CS-I & $6.14 \pm 0.09 \mathrm{~A} \alpha$ & n.d. & $8.53 \pm 0.04 \gamma$ & n.d. & $8.63 \pm 0.06^{\mathrm{AB} \gamma}$ & $8.58 \pm 0.02 \mathrm{~B} \gamma$ & $8.25 \pm 0.02^{B} \beta$ \\
\hline D-CS-O & $8.76 \pm 0.04^{\mathrm{D} \alpha}$ & n.d. & $8.17 \pm 0.08^{\beta}$ & n.d. & $8.61 \pm 0.05^{\mathrm{AB} \gamma}$ & $8.27 \pm 0.12^{\mathrm{A} \beta}$ & $8.12 \pm 0.07 \mathrm{~A} \beta$ \\
\hline D-MR-I & $6.33 \pm 0.20 \mathrm{AB} \alpha$ & n.d. & $8.54 \pm 0.08^{\beta}$ & n.d. & $8.62 \pm 0.13 \mathrm{AB} \beta$ & $8.52 \pm 0.11 \mathrm{AB} \beta$ & $8.50 \pm 0.11 \mathrm{AB} \beta$ \\
\hline D-MR-O & $6.50 \pm 0.05^{\mathrm{B} \alpha}$ & n.d. & $8.58 \pm 0.13^{\beta \gamma}$ & n.d. & $8.11 \pm 0.16^{\mathrm{B} \beta}$ & $8.78 \pm 0.10^{\mathrm{B} \gamma}$ & $8.32 \pm 0.12 \mathrm{AB} \beta$ \\
\hline Mean & $6.80 \pm 0.94^{\alpha}$ & & $8.39 \pm 0.23 \beta$ & $8.47 \pm 0.12^{\beta}$ & $8.53 \pm 0.22 \beta$ & $8.53 \pm 0.18^{\beta}$ & $8.38 \pm 0.19 \beta$ \\
\hline
\end{tabular}

Legend: ${ }^{A}, \mathrm{~B}, \mathrm{C}, \mathrm{D}: P<0.05$ within plant and column; ${ }^{\alpha, \beta, \gamma, \delta}: P<0.05$ within plant and row; n.d.: not done; ${ }^{*}$ t: days. 
The comparison along the time is not the effect under study, but it allowed to verify if there were deviations in the correct development of fermentation. If this had happened, this could have been attributed to the different composition (e.g., intramuscular fat, type of fat.) of the meat due to the breed. In Figure 1 it can be observed that, apart from to, the coefficients of variation among the trials per each time is higher in plant $\mathrm{T}$ than in plant $\mathrm{D}$. This can be attributed to the different procedures and technologies applied in the two plants. The industrial plant (D), using exactly the same procedures at each production phase, as well as an optimized protocol of drying and ripening in chambers with a more accurate system to control humidity and temperature, resulted in a major standardization of the microbial fermentation and, consequently, of the final product. On the other hand, although in the artisanal plant $(\mathrm{T})$ there is a higher coefficient of variability, it is possible to note that fermentation has progressed flawlessly. In this case, no microbial starters have been added, but nevertheless the production technology has allowed the correct development of the indigenous LAB, which in nine days have reached the same values as those inoculated in plant D. Finally, looking at day 0 , it seems that the counts of the trials performed using pork meat from outdoor breeding system were significantly higher than those of the indoor breeding system. Probably the outdoor breeding system has brought the pigs to smear/soil more than the indoor breeding system, and therefore to increase the microbial load of the skin, which during the slaughter has favoured a greater contamination of the carcass.

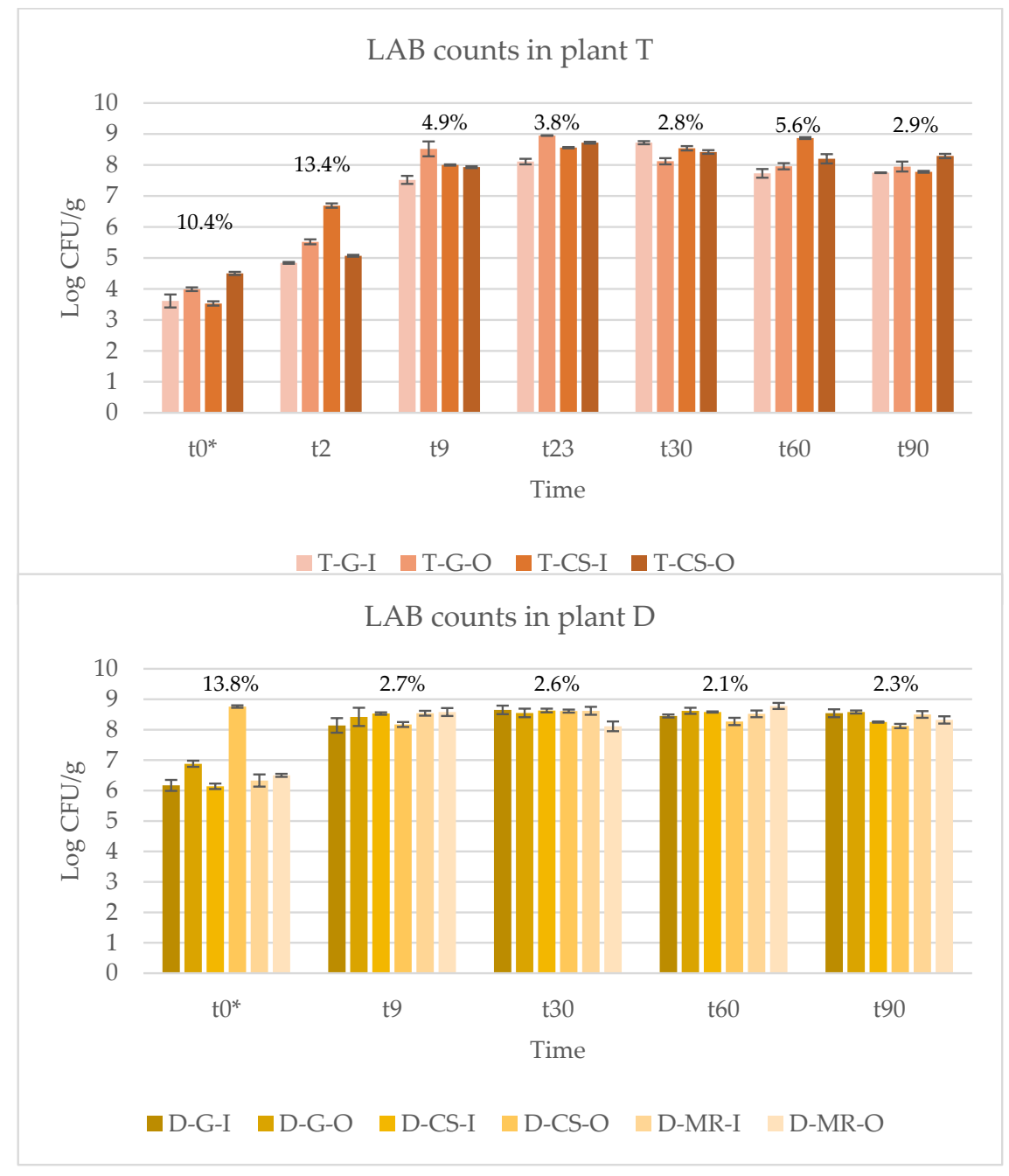

Figure 1. LAB development during ripening in the different trials. Industrial plant (D) and traditional plant (T) whose meats derived from pigs of three breeds, Goland (G), Cinta Senese (CS), and Mora Romagnola (MR) that were indoor $(\mathrm{I})$ or outdoor $(\mathrm{O})$ housed. The coefficient of variation among trials per time is shown above histograms. 


\subsection{Dynamics of the Detected Species}

In order to obtain information regarding the species involved in the fermentation and their relative concentration, DGGE fingerprints were obtained from cells collected in bulk from the count plates for each dilution, after colony enumeration. From the DGGE fingerprints (Figure 2), the following species, as responsible for the fermentation of sausages, were detected: Lb. sakei, Lb. casei, Lb. cuvatus, Lb. graminis, Lactococcus garviae, Leuconostoc mesenteoides, and Pediococcus pentosaceus.

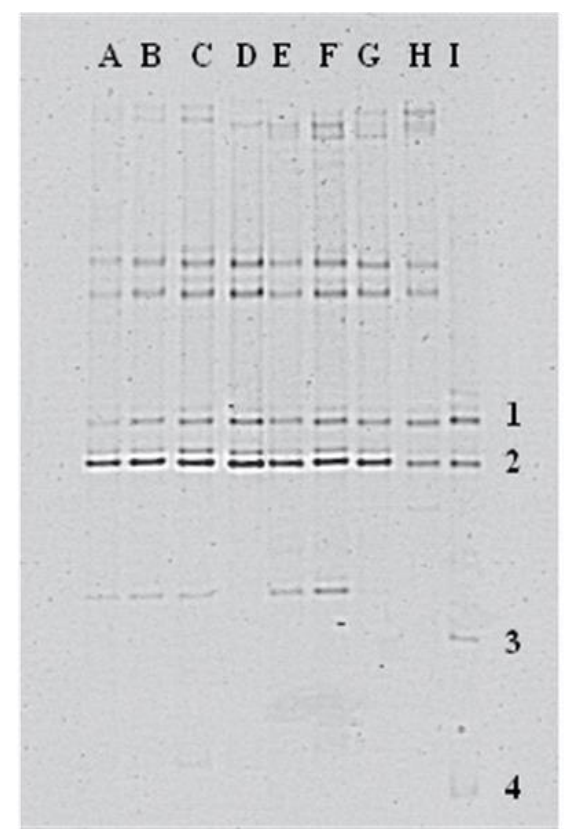

Figure 2. Examples of PCR-DGGE fingerprints obtained from the bulk suspensions. Lines A, B, C, D, E, $\mathrm{F}, \mathrm{G}$ correspond to the samples coming from samples T-CS-I. Line I correspond to the standard used as a control: 1-Lb. curvatus, DSM 20019; 2-Lb. sakei, DSM 6333; 3-Lb. brevis, DSM 20054; 4-Lb. casei, DSM 20011.

In particular, $L b$. sakei constituted the predominant specie over the monitored period. In this study, it has been therefore confirmed that $L b$. sakei remains the overriding species in fermented meat products, as demonstrated by several authors, who reported percentages of isolation starting from $42 \%$ in Italian-Greek suasages, increasing to a percentage of $76 \%-89 \%$ in Spanish sausages and reaching the $100 \%$ in French sausages [21,27,51-54].

In samples from the industrial plant (plant D, Table 2) a limited number of species, ranging from two to four, were detected in the different trials. Lb. sakei and P. pentosaceus were present in all monitored fermentations and showed the highest counts during the entire fermentation process. Considering that in these trials P. pentosaceus was inoculated as starter culture at a level of about $10^{6}$ $\mathrm{CFU} / \mathrm{g}$, the results highlighted the capability of $L b$. sakei to dominate in this peculiar ecological niche being the more adaptable species at the specific environmental conditions of fermented meats. In fact, although from the beginning of fermentation high counts of P. pentosaceus were present, Lb. sakei was able to compete and achieve comparable concentrations, remaining almost stable throughout the fermentation process. The development of $L b$. sakei was favoured by the temperature of the first stage of ripening $\left(22^{\circ} \mathrm{C}\right)$, which is more adapted to Lb. sakei than P. pentosaceus. Indeed, the choice to use a first ripening temperature lower than the optimal temperature for $P$. pentosaceous growth was determined by the aim of reducing the rate of acidification by this species, in order to obtain a more flavourful product. 
Table 2. Plate dilutions at which each identified species were detected per sampling point from the industrial plant (D).

\begin{tabular}{|c|c|c|c|c|c|}
\hline \multirow{2}{*}{$\begin{array}{c}\text { Identified Species } \\
\text { (NCBI Accession Number) }\end{array}$} & to & t9 & $\mathbf{t} 30$ & t60 & t90 \\
\hline & \multicolumn{5}{|c|}{ Plate Dilution at Which the Identified Species were Detected } \\
\hline \multicolumn{6}{|c|}{ D-G-I } \\
\hline Lactobacillus sakei (NR_113821.1) & $10^{-2}$ & n.d. & n.d. & n.d. & $10^{-6}$ \\
\hline $\begin{array}{l}\text { Lactobacillus curvatus } \\
\text { (NR_113334.1) }\end{array}$ & n.d. & n.d. & n.d. & n.d. & $10^{-7}$ \\
\hline Lactobacillus casei (NR_041893.1) & n.d. & n.d. & $10^{7}$ & n.d. & $10^{-7}$ \\
\hline $\begin{array}{c}\text { Pediocossus pentosaceus } \\
\text { (NR_042058.1) }\end{array}$ & $10^{-7}$ & $10^{-7}$ & $10^{-7}$ & $10^{-7}$ & $10^{-7}$ \\
\hline \multicolumn{6}{|c|}{ D-G-O } \\
\hline Lactobacillus sakei (NR_113821.1) & $10^{-3}$ & $10^{-6}$ & $10^{-7}$ & $10^{-7}$ & $10^{-7}$ \\
\hline $\begin{array}{l}\text { Lactobacillus curvatus } \\
\text { (NR_113334.1) }\end{array}$ & n.d. & n.d. & $10^{-6}$ & $10^{-6}$ & $10^{-6}$ \\
\hline $\begin{array}{l}\text { Pediocossus pentosaceus } \\
\text { (NR_042058.1) }\end{array}$ & $10^{-6}$ & $10^{-6}$ & $10^{-7}$ & $10^{-7}$ & $10^{-7}$ \\
\hline \multicolumn{6}{|c|}{ D-CS-I } \\
\hline Lactobacillus sakei (NR_113821.1) & $10^{-2}$ & $10^{-6}$ & $10^{-7}$ & $10^{-7}$ & $10^{-6}$ \\
\hline $\begin{array}{c}\text { Pediocossus pentosaceus } \\
\text { (NR_042058.1) }\end{array}$ & $10^{-5}$ & $10^{-7}$ & $10^{-7}$ & $10^{-7}$ & $10^{-7}$ \\
\hline \multicolumn{6}{|c|}{ D-CS-O } \\
\hline Lactobacillus sakei (NR_113821.1) & n.d. & n.d. & n.d. & $10^{-5}$ & $10^{-4}$ \\
\hline $\begin{array}{l}\text { Lactobacillus curvatus } \\
\text { (NR_113334.1) }\end{array}$ & n.d. & n.d. & n.d. & $10^{-5}$ & $10^{-5}$ \\
\hline $\begin{array}{l}\text { Pediocossus pentosaceus } \\
\text { (NR_042058.1) }\end{array}$ & $10^{-6}$ & $10^{-7}$ & $10^{-7}$ & $10^{-6}$ & $10^{-7}$ \\
\hline \multicolumn{6}{|c|}{ D-MR-I } \\
\hline Lactobacillus sakei (NR_113821.1) & n.d. & n.d. & n.d. & $10^{-6}$ & $10^{-4}$ \\
\hline $\begin{array}{c}\text { Pediocossus pentosaceus } \\
\text { (NR_042058.1) }\end{array}$ & $10^{-5}$ & $10^{-7}$ & $10^{-7}$ & $10^{-7}$ & $10^{-6}$ \\
\hline \multicolumn{6}{|c|}{ D-MR-O } \\
\hline Lactobacillus sakei (NR_113821.1) & n.d. & $10^{-7}$ & $10^{-7}$ & $10^{-7}$ & $10^{-7}$ \\
\hline $\begin{array}{l}\text { Lactobacillus curvatus } \\
\text { (NR_113334.1) }\end{array}$ & n.d. & $10^{-7}$ & $10^{-7}$ & $10^{-7}$ & $10^{-7}$ \\
\hline $\begin{array}{l}\text { Pediocossus pentosaceus } \\
\quad(\text { NR_042058.1) }\end{array}$ & $10^{-6}$ & $10^{-7}$ & $10^{-7}$ & $10^{-7}$ & $10^{-7}$ \\
\hline
\end{tabular}

Other than these two species, also Lb. curvatus was found, confirming to be one of the most recurrently species, suggesting that, in association with $L b$. sakei, it predominantly leads meat fermentations [33,55-58]. In fact, Lb. curvatus was present during the ripening of industrial products, except for those obtained from Cinta Senese and Mora Romagnola indoor breeding system productions (D-CS-I, D-MR-I).

In the artisanal products (plant $\mathrm{T}$, Table 3 ), this species had a more constant trade, from the stuffing to the end of ripening, where it amounted to the highest dilutions $\left(10^{-6}-10^{-7}\right)$. Instead, in the industrial productions (D), it was constantly founded in Goland outdoor, Cinta Senese indoor and Mora Romagnola outdoor breeding system products (D-G-O, D-CS-I, D-MR-O), whereas in the other cases $L b$. sakei was only detected at the end of the ripening. 
Table 3. Plate dilutions at which each identified species were detected per sampling point from the artisanal plant $(\mathrm{T})$.

\begin{tabular}{|c|c|c|c|c|c|c|c|}
\hline \multirow{2}{*}{$\begin{array}{c}\text { Identified Species } \\
\text { (NCBI Accession Number) }\end{array}$} & to & t2 & t9 & $\mathbf{t} 23$ & $\mathbf{t} 30$ & t60 & t90 \\
\hline & \multicolumn{7}{|c|}{ Plate Dilution at Which the Identified Species were Detected } \\
\hline \multicolumn{8}{|c|}{ T-G-I } \\
\hline $\begin{array}{l}\text { Lactobacillus sakei } \\
\text { (NR_113821.1) }\end{array}$ & $10^{-2}$ & $10^{-5}$ & $10^{-5}$ & $10^{-5}$ & $10^{-6}$ & $10^{-6}$ & n.d. \\
\hline $\begin{array}{l}\text { Lactobacillus curvatus } \\
\text { (NR_113334.1) }\end{array}$ & $10^{-2}$ & $10^{-4}$ & $10^{-5}$ & $10^{-5}$ & $10^{-6}$ & $10^{-6}$ & $10^{-6}$ \\
\hline $\begin{array}{c}\text { Lactobacillus casei } \\
\text { (NR_041893.1) }\end{array}$ & $10^{-2}$ & $10^{-4}$ & $10^{-6}$ & n.d. & n.d. & n.d. & n.d. \\
\hline $\begin{array}{l}\text { Lactobacillus graminis } \\
\text { (NR_042438.1) }\end{array}$ & n.d. & n.d. & n.d. & n.d. & n.d. & n.d. & $10^{-6}$ \\
\hline $\begin{array}{l}\text { Lactococcus garviae } \\
\text { (KU898985.1) }\end{array}$ & n.d. & $10^{-3}$ & $10^{-6}$ & $10^{-7}$ & n.d. & n.d. & n.d. \\
\hline $\begin{array}{c}\text { Leuconostoc mesenteroides } \\
\text { (DQ297412.1) }\end{array}$ & n.d. & n.d. & n.d. & $10^{-7}$ & $10^{-6}$ & $10^{-6}$ & n.d. \\
\hline $\begin{array}{c}\text { Pediocossus pentosaceus } \\
\text { (NR_042058.1) }\end{array}$ & n.d. & n.d. & n.d. & $10^{-5}$ & $10^{-5}$ & n.d. & n.d. \\
\hline \multicolumn{8}{|c|}{ T-G-O } \\
\hline $\begin{array}{l}\text { Lactobacillus sakei } \\
\text { (NR_113821.1) }\end{array}$ & $10^{-2}$ & $10^{-4}$ & $10^{-7}$ & $10^{-7}$ & $10^{-6}$ & $10^{-6}$ & $10^{-6}$ \\
\hline $\begin{array}{l}\text { Lactobacillus curvatus } \\
\text { (NR_113334.1) }\end{array}$ & $10^{-2}$ & $10^{-4}$ & $10^{-7}$ & $10^{-7}$ & $10^{-6}$ & n.d. & n.d. \\
\hline $\begin{array}{l}\text { Leuconostoc mesenteroides } \\
(D Q 297412.1)\end{array}$ & $10^{2}$ & n.d. & n.d. & n.d. & n.d. & n.d. & n.d. \\
\hline \multicolumn{8}{|c|}{ T-CS-I } \\
\hline $\begin{array}{l}\text { Lactobacillus sakei } \\
\text { (NR_113821.1) }\end{array}$ & $10^{-2}$ & $10^{-6}$ & $10^{-6}$ & $10^{-7}$ & $10^{-7}$ & $10^{-7}$ & $10^{-7}$ \\
\hline $\begin{array}{l}\text { Lactobacillus curvatus } \\
\text { (NR_113334.1) }\end{array}$ & n.d. & $10^{-6}$ & $10^{-6}$ & $10^{-7}$ & $10^{-7}$ & $10^{-7}$ & $10^{-7}$ \\
\hline $\begin{array}{c}\text { Lactococcus garviae } \\
\text { (KU898985.1) }\end{array}$ & $10^{-3}$ & $10^{-4}$ & n.d. & n.d. & n.d. & n.d. & n.d. \\
\hline $\begin{array}{c}\text { Leuconostoc mesenteroides } \\
\text { (DQ297412.1) }\end{array}$ & $10^{-2}$ & $10^{-6}$ & n.d. & $10^{-5}$ & $10^{-7}$ & n.d. & n.d. \\
\hline \multicolumn{8}{|c|}{ T-CS-O } \\
\hline $\begin{array}{l}\text { Lactobacillus sakei } \\
\text { (NR_113821.1) }\end{array}$ & n.d. & $10^{-3}$ & $10^{-7}$ & $10^{-7}$ & $10^{-7}$ & $10^{-6}$ & $10^{-7}$ \\
\hline $\begin{array}{l}\text { Lactobacillus curvatus } \\
\text { (NR_113334.1) }\end{array}$ & n.d. & $10^{-3}$ & $10^{-7}$ & $10^{-7}$ & $10^{-7}$ & $10^{-6}$ & $10^{-7}$ \\
\hline $\begin{array}{l}\text { Lactococcus garviae } \\
\text { (KU898985.1) }\end{array}$ & n.d. & $10^{-3}$ & n.d. & n.d. & n.d. & n.d. & n.d. \\
\hline $\begin{array}{l}\text { Leuconostoc mesenteroides } \\
(D Q 297412.1)\end{array}$ & $10^{-3}$ & n.d. & n.d. & n.d. & n.d. & n.d. & n.d. \\
\hline
\end{tabular}

Considering the artisanal plant, $L b$. sakei and $L b$. curvatus were detected in all the monitored products, especially after the ninth day of ripening, always at the higher dilutions $\left(10^{-5}-10^{-7}\right)$, once more confirming their dominant role also in spontaneous fermentations. Lb. casei was the least common species identified in the sausages from both the plants, but it appeared at high concentration at 90 days for the industrial D-G-I trial, and only from zero to nine days in the artisanal spontaneous fermentation T-G-I. Considering the relevant aspects related to the probiotic characteristics of this specie, their presence as spontaneous microflora in this products supports gives clear evidence that this species 
could be used as starter culture to provide the market with a new nutritional alternative that increases the variety of existing probiotic products, as well as increasing the added value of sausages $[59,60]$.

Other species were detected during the process, but they were involved only in some of the considered productions. The equilibrium among the different species as well as the presence or absence of some of them are responsible for the production of different aroma characteristics in the final product; characteristics that are even more evident in the comparison of artisanal rather than industrial products.

Leuconostoc mesenteroides was identified in each of the artisanal productions, till the $60^{\text {th }}$ day of ripening. Lactococcus garviae was detected in each monitored sausage, except for the Goland outdoor breeding system products (T-G-O). Lb. casei, Lb. graminis, and Pediococcus pentosaceus were only found in the Goland indoor breeding system products (T-G-I).

Lb. curvatus was constantly participating in artisanal productions (T), especially in sausages obtained from Cinta Senese breed, reaching the highest dilutions $\left(10^{-7}\right)$ at the end of ripening. Products from Goland breed showed some differences depending on the breeding system: in T-G-I, Lb. curvatus was always detected during ripening, whereas in T-G-O, this species was founded only in the first step of the process. Fermented sausages from the industrial plan (D) showed an irregular presence of $L b$. curvatus during ripenings. In some cases, it was absent, in other ones, it was detected only at the last steps of ripening, and in other trials, this species was found all long the production process. Pediococcus pentosaceus had a specific role in industrial sausage production (D) due to its use as a microbial starter; indeed, in this case, this species was detected, from the stuffing to the end of the ripening, at the greater dilutions. In the artisanal productions (T), P. pentosaceus was founded only in sausages obtained by Goland pork breed at the sampling point named t30. Leuconostoc mesenteroides was observed only in the artisanal products $(\mathrm{T})$, with an irregular presence. In samples from the outdoor breeding system, this species was detected at the moment of stuffing, in low dilutions $\left(10^{-2}-10^{-3}\right)$; in samples from Cinta senese indoor breeding system (T-CS-I), L. mesenteroides was present till t30 sampling time, in increasing dilutions (from $10^{-2}$ to $10^{-7}$ ); in sausages from Goland indoor breeding system (T-G-I), this species appeared from $\mathrm{t} 23$ to $\mathrm{t} 60$ sampling points, in high dilutions $\left(10^{-6}-10^{-7}\right)$. Lb. casei was detected in both plants $(\mathrm{T}, \mathrm{D})$, but only in products obtained from Goland indoor breeding system, during the first step of ripening. Lactococcus garviae was detected in artisanal products $(\mathrm{T})$ deriving from indoor breeding, at the first sampling times and in the highest dilutions $\left(10^{-7}\right)$. Lactococcus garvieae was rarely associated to fermented sausages [15,51] and it has been classified as an emerging pathogen found in animals (cows, buffalos, farmed fish), as well as in human clinical isolates. Since then, many papers stated that this bacterium is a human gastrointestinal commensal or transient bacterium, which can cause a variety of infections [61]. Lb. graminis was present only in artisanal fermented sausages (T), from Goland indoor breeding system, during the middle period of ripening ( $\mathrm{t} 2-\mathrm{t} 23)$, in high dilutions $\left(10^{-6}-10^{-7}\right)$. This species was at first isolated at the end fermentation of grass silage. Noteworthy that, this heterofermentative species, which is not frequently isolated from meat products, has a low DNA-DNA homology value with the type strains of $L$. sakei and L. curvatus, but they were similar with respect to $\mathrm{D}(-)$ - and $\mathrm{L}(+)$ - lactate formation, Rf-values of the D- and L-LDH, G+C content of the DNA and the L-Lys-D-Asp murein type [62].

\subsection{Fingerprint Analyses}

Statistical analysis was also applied to the DNA fingerprints obtained by PCR-DGGE. The results of the cluster analysis using the Pearson product-moment correlation coefficient were shown in Figure 3. A similarity coefficient of 53\% was arbitrarily selected. As shown (Figure 3), a total of 35 clusters were discerned. Except for clusters XV, XVII, XXVII and XXIX, all the others grouped samples produced in the same plant, clearly suggesting that they were plant-specific clusters. Half of the groups included only two, three, or four samples, the others are composed of six or more samples. The most relevant clusters were the number XIII (17 fingerprints, plant T), XX (16 fingerprints, plant D), XXV (13 fingerprints, plant D) and XXVII (18 fingerprints, plant T). Furthermore, 22 clusters were found 
to be also breed-specific. Only nine samples did not belong to any cluster. Subsequently, a different cluster analysis based on the Dice correlation coefficient ( $60 \%$ coefficient of similarity) was performed, and the results are presented in Figure 4 . The second analysis confirmed the previous results: 20 clusters of 33 resulted to be plant-specific, 15 of them included two, three, or four samples and the others had five or more samples. The most relevant clusters are the number XI (15 fingerprints, plant D), XXIV (14 fingerprints, plant D) and XXVIII (14 fingerprints, plant D). This analysis confirmed also the presence of breed-specific clusters (22 of 33) and 12 samples did not belong to any cluster.

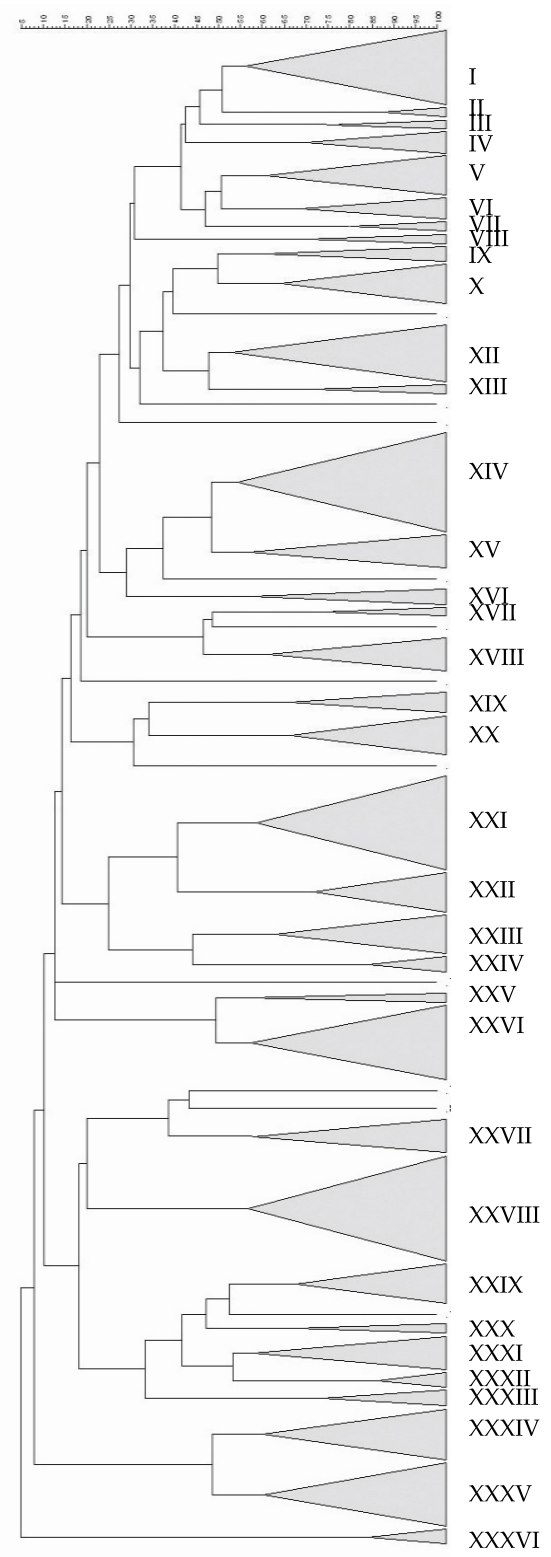

\begin{tabular}{|c|c|c|c|c|c|c|}
\hline \multirow[t]{3}{*}{ cluster } & \multirow{3}{*}{$\begin{array}{c}\text { number of } \\
\text { samples } \\
\text { per cluster }\end{array}$} & \multicolumn{5}{|c|}{ cluster composition } \\
\hline & & \multicolumn{2}{|c|}{$\mathrm{T}$} & \multicolumn{3}{|c|}{ D } \\
\hline & & G & CS & G & CS & MR \\
\hline I & 13 & - & - & - & 1 & 12 \\
\hline II & 2 & 2 & - & - & - & - \\
\hline III & 2 & 2 & - & - & - & - \\
\hline IV & 4 & 4 & - & - & - & - \\
\hline $\mathrm{v}$ & 7 & 1 & 6 & - & - & - \\
\hline VI & 4 & 4 & - & - & - & - \\
\hline VII & 2 & 2 & - & - & - & - \\
\hline VIII & 2 & - & - & - & - & 2 \\
\hline IX & 3 & 2 & 1 & - & - & - \\
\hline $\mathrm{x}$ & 7 & - & - & - & - & 7 \\
\hline $\mathrm{XI}$ & 10 & - & - & - & - & 10 \\
\hline XII & 2 & - & - & - & - & 2 \\
\hline XIII & 17 & 12 & 5 & - & - & - \\
\hline XIV & 6 & 2 & 4 & - & - & - \\
\hline $\mathrm{xV}$ & 3 & - & 1 & 2 & - & - \\
\hline XVI & 2 & 2 & - & - & - & - \\
\hline XVII & 6 & - & 5 & 1 & - & - \\
\hline XVIII & 4 & - & - & 2 & 2 & - \\
\hline $\mathrm{XIX}$ & 7 & - & - & 5 & 2 & - \\
\hline$x x$ & 16 & - & - & - & 13 & 3 \\
\hline XXI & 7 & - & - & - & 7 & - \\
\hline XXII & 7 & - & - & - & 7 & - \\
\hline XXIII & 3 & - & 3 & - & - & - \\
\hline XXIV & 2 & - & - & - & 2 & - \\
\hline$x \mathrm{xv}$ & 13 & - & - & - & 13 & - \\
\hline XXVI & 6 & - & 4 & 1 & 1 & - \\
\hline XXVII & 18 & 4 & 14 & - & - & - \\
\hline XXVIII & 7 & 6 & - & 1 & - & - \\
\hline XXIX & 2 & - & 2 & - & - & - \\
\hline$x x x$ & 6 & 6 & - & - & - & - \\
\hline XXXI & 3 & - & 3 & - & - & - \\
\hline XXXII & 3 & - & 3 & - & - & - \\
\hline XXXIII & 9 & - & - & 9 & - & - \\
\hline XxxIV & 11 & - & - & 8 & 3 & - \\
\hline XXXV & 3 & - & - & - & - & 3 \\
\hline
\end{tabular}

Figure 3. Cluster analysis using Pearson product-moment correlation coefficients and unweighted pair group method using an arithmetic average (UPGMA) of the profiles obtained from the fingerprinting analysis of the different fermentations. A similarity coefficient of $53 \%$ was arbitrarily chosen. Identified clusters are indicated with roman numerals. Cluster composition is defined in the table within the figure. 


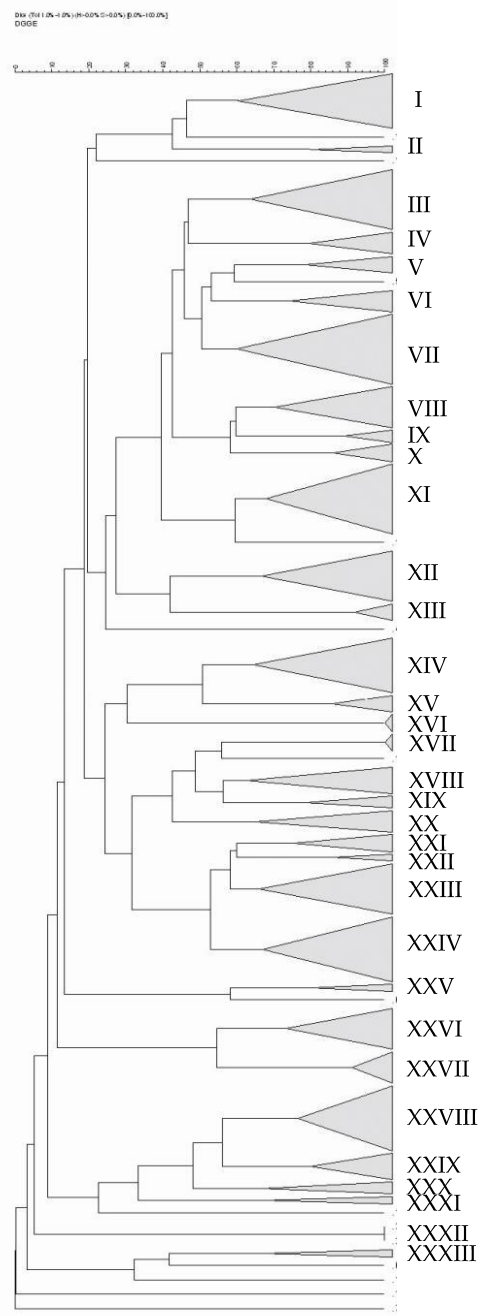

\begin{tabular}{|c|c|c|c|c|c|c|}
\hline \multirow[t]{3}{*}{ cluster } & \multirow{3}{*}{$\begin{array}{c}\text { number of } \\
\text { isolates per } \\
\text { clusters }\end{array}$} & \multicolumn{5}{|c|}{ cluster composition } \\
\hline & & \multicolumn{2}{|c|}{$\mathrm{T}$} & \multicolumn{3}{|c|}{ D } \\
\hline & & G & CS & G & CS & MR \\
\hline I & 12 & 7 & 5 & - & - & - \\
\hline II & 2 & 2 & - & - & - & - \\
\hline III & 13 & 10 & 1 & 2 & - & - \\
\hline IV & 5 & - & 5 & - & - & - \\
\hline $\mathrm{V}$ & 4 & - & 4 & - & - & - \\
\hline VI & 5 & - & 5 & - & - & - \\
\hline VII & 15 & - & 5 & - & 10 & - \\
\hline VIII & 12 & 3 & 9 & - & - & - \\
\hline IX & 3 & - & 3 & - & - & - \\
\hline$x$ & 4 & - & 4 & - & - & - \\
\hline $\mathrm{XI}$ & 15 & - & - & 11 & 4 & - \\
\hline XII & 11 & 10 & 1 & - & - & - \\
\hline XIII & 4 & - & 4 & - & - & - \\
\hline XIV & 12 & - & - & - & - & 12 \\
\hline $\mathrm{xV}$ & 4 & - & - & - & - & 4 \\
\hline XVI & 4 & - & - & - & 4 & - \\
\hline XVII & 4 & - & 4 & - & - & - \\
\hline XVIII & 6 & 2 & 4 & - & - & - \\
\hline XIX & 3 & - & 3 & - & 2 & - \\
\hline$x x$ & 5 & 4 & - & - & - & 1 \\
\hline XXI & 4 & - & - & 4 & - & - \\
\hline XXII & 2 & - & - & - & 2 & - \\
\hline XXIII & 11 & - & - & - & 11 & - \\
\hline XXIV & 14 & - & - & 13 & 1 & - \\
\hline$x x v$ & 2 & - & - & - & 13 & - \\
\hline XXVI & 9 & - & - & - & - & 9 \\
\hline XXVII & 7 & - & - & - & - & 7 \\
\hline XXVIII & 14 & - & - & - & 10 & 4 \\
\hline XXIX & 6 & - & - & - & 6 & - \\
\hline$x x x$ & 3 & - & - & - & 3 & - \\
\hline XXXI & 2 & - & - & - & - & 2 \\
\hline XXXII & 2 & 2 & - & - & - & - \\
\hline XXXIII & 2 & 1 & 1 & - & - & - \\
\hline
\end{tabular}

Figure 4. Cluster analysis using Dice product-moment correlation coefficients and unweighted pair group method using an arithmetic average (UPGMA) of the profiles obtained from the fingerprinting analysis of the different fermentations. A similarity coefficient of $60 \%$ was arbitrarily chosen. Identified clusters are indicated with roman numerals. Cluster composition is defined in the table within the figure.

The congruence of the data obtained with the use of both Pearson and Dice product-momentcorrelation coefficients proves the significance of the result, demonstrating the existence of plant- and breed-specificity among the monitored fermentations. If the plant effect could be simply explained as an environmental selection during the time of the microflora, which forms a biofilm on structures and equipment, the breed effect could result from the different chemical-physical characteristics of the raw meats, more precisely the type and quantity of intramuscular fat, which are strictly correlated to pork breed. Actually, during grinding and/or mixing, the rise in temperature due to friction can cause the melting of low melting point fats, with consequent difficulties in the dehydration process during drying and ripening, leading to irregular changes in water activity (Aw) that influence the microbial species equilibrium. Finally, most of the breed-specific clusters, obtained by both the correlation coefficients, showed homogeneous samples also concerning the different breeding systems. Therefore, it's possible to say that the microbial ecology is influenced also by the breeding system, as speculated in the introduction. However, it is possible that other factors may intervene and change the microflora characterizing the animal and, consequently, the meat. In our experiment, 
for example, seasonality was not taken into account, to avoid adding too many variables. It should be considered, however, that, among others, humidity and environmental temperature can influence both the environmental microflora and the state of health of the animal, with consequent modification of the intestinal microflora, leading to variations of the isolated species. Furthermore, it is well known that small variations can always be present, considering the differences between the autochthonous and allochthonous microflora, but the former will always have a character of stability, due to the fact that being more adapted to that particular environment, it will also be more incisive than the allochthonous ones. These results confirm the data from previous studies, which stated that the production technologies applied in a specific production plant and the pork breed select a characteristic and specific microbial ecology $[6,7,34,63]$.

Author Contributions: Conceptualization, L.I.; methodology, L.I.; validation, L.I. and G.C.; formal analysis, M.C. and L.I.; investigation, A.M. and D.B.; resources, L.I. and G.C.; data curation, L.I. and M.C.; writing-original draft preparation, A.M. and L.I.; writing-review and editing, L.I. and G.C.; visualization, L.I.; supervision, L.I.; project administration, L.I.; funding acquisition, L.I. and G.C. All authors have read and agreed to the published version of the manuscript.

Funding: This research was funded by ERSA-FVG.

Conflicts of Interest: The authors declare no conflict of interest.

\section{References}

1. Cocolin, L.; Rantsiou, K.; Iacumin, L.; Urso, R.; Cantoni, C.; Comi, G. Study of the ecology of fresh sausages and characterization of populations of lactic acid bacteria by molecular methods. Appl. Environ. Microbiol. 2004, 70, 1883-1894. [CrossRef] [PubMed]

2. Iacumin, L.; Manzano, M.; Comi, G. Catalase positive cocci in fermented sausages: Variability due to different pork breeds, breeding system and sausage production technology. Food Microbiol. 2012, 29, $178-186$. [CrossRef] [PubMed]

3. Cocolin, L.; Manzano, M.; Cantoni, C.; Comi, G. Denaturing gradient gel electrophoresis analysis of the 16S rRNA gene V1 region to monitor dynamic changes in the bacterial population during fermentation of Italia sausages. Appl. Environ. Microbiol. 2001, 67, 5113-6282. [CrossRef]

4. Lücke, F.K. Fermented sausages. In Microbiology of Fermented Food; Wood, B.J.B., Ed.; Elsevier Applied Science: New York, NY, USA, 1985.

5. Iacumin, L.; Osualdini, M.; Bovolenta, S.; Boscolo, D.; Chiesa, L.; Panseri, S.; Comi, G. Microbial, chemico-physical and volatile aromatic compounds characterization of Pitina PGI, a peculiar sausage-like product of North East Italy. Meat Sci. 2020, 162, 108081. [CrossRef]

6. Coppola, R.; Marconi, E.; Rossi, F.; Dellaglio, F. Artisanal production of Naples-types salami: Chamical and microbiological aspects. Ital. J. Food Sci. 1995, 7, 57-62.

7. Coppola, R.; Iorizzo, M.; Saotta, R.; Sorrentino, E.; Grazia, L. Characterization of micrococci and staphylococci isolated from sopressata molisana, a Southern Italy fermented sausage. Food Microbiol. 1997, 14, 47-53. [CrossRef]

8. Iacumin, L.; Comi, G.; Cantoni, C.; Cocolin, L. Ecology and dynamics of coagulase-negative cocci isolated from naturally fermented Italian sausages. Syst. Appl. Microbiol. 2006, 29, 480-486. [CrossRef]

9. Lücke, F.K.; Hechelmann, H. Starter cultures for dry sausages and raw ham. Fleischwirt 1987, 66, 1505-1508.

10. Demeyer, D.I.; Verplaetse, A.; Gistelink, M. Fermentation of meat: An integrated process. Belg. J. Food Chem. Biotechnol. 1986, 41, 131-140.

11. Baka, A.M.; Papavergou, E.J.; Pragalaki, T.; Bloukas, J.G.; Kotzekidou, P. Effect of selected autochthonous starter cultures on processing and quality characteristics of Greek fermented sausages. LWT Food Sci. Technol. 2011, 44, 54-61. [CrossRef]

12. Geisen, R.; Lüke, F.K.; Krockel, L. Starter and protective cultures for meat and meat products. Fleischwirt 1992, 72, 894-898.

13. Selgas, M.D.; Sanz, B.; Ordonez, J.A. Selected characteristics of micrococci isolated from Spanish dry fermented sausages. Food Microbiol. 1988, 5, 185-193. [CrossRef]

14. Varnam, A.H.; Sutherland, J.P. Meat and Meat Products; Chapman \& Hall: London, UK, 1995. 
15. Jones, R.J.; Hussein, H.M.; Zaigorec, M.; Brightnell, G.; Tagg, J.R. Isolation of lactic acid bacteria with inhibitory activity against pathogens and spoilage organisms associated with fresh meat. Food Microbiol. 2008, 25, 228-234. [CrossRef] [PubMed]

16. Rantsiou, K.; Urso, R.; Iacumin, L.; Cantoni, C.; Cattaneo, P.; Comi, G.; Cocolin, L. Culture-Dependent and -Independent Methods to Investigate the Microbial Ecology of Italian Fermented Sausages. Appl. Environ. Microbiol. 2005, 4, 1977-1986. [CrossRef]

17. Comi, G.; Iacumin, L. The use of bioprotective cultures. In Strategies to Obtaining Healthier Foods; Nova Science Publishers, Inc. Hauppauge: New York, NY, USA, 2017.

18. Holzapfel, R.W.; Geisen, R.; Schillinger, U. Biological preservation of foods with reference to protective cultures, becteriocins and food-grade enzymes. Int. J. Food Microbiol. 1995, 24, 343-362. [CrossRef]

19. Stiles, M.E. Biopreservation by lactic acid bacteria. Antonie Von Leeuwenhoek 1996, 70, 331-345. [CrossRef] [PubMed]

20. Ben Omar, N.; Ampe, F. Microbial community dynamics during production of the Mexican fermented maize dough pozol. Appl. Eviron. Microbiol. 2000, 66, 3664-3673. [CrossRef] [PubMed]

21. Coppola, S.; Mauriello, G.; Aponte, M.; Moschetti, G.; Villani, F. Microbial succession during ripening of Naples-type salami, a southern Italian fermented sausage. Meat Sci. 2000, 56, 321-329. [CrossRef]

22. Fontana, C.; Vignolo, G.; Cocconcelli, P.S. PCR-DGGE analysis for the identification of microbial populations from Argentinean dry fermented sausages. J. Microbiol. Methods 2005, 63, 254-263. [CrossRef]

23. Iacumin, L.; Cecchini, F.; Manzano, M.; Osualdini, M.; Boscolo, D.; Orlic, S.; Comi, G. Description of the microflora of sourdoughs by culture-dependent and culture-independent methods. Food Microbiol. 2009, 26, 128-135. [CrossRef]

24. Klijn, N.; Weerkamp, A.H.; de Vos, W.M. Identification of mesophilic lactic acid bacteria by using polymerase chain reaction-amplified variable regions of $16 \mathrm{~S}$ rRNA and specific DNA probes. Appl. Environ. Microbiol. 1991, 57, 3390-3393. [CrossRef] [PubMed]

25. Franciosa, I.; Alessandria, V.; Dolci, P.; Rantsiou, K.; Cocolin, L. Sausage fermentation and starter cultures in the era of molecular biologymethods. Int. J. Food Microbiol. 2018, 279, 26-32. [CrossRef] [PubMed]

26. Andrighetto, C.; Zampese, L.; Lombardi, A. RAPD-PCR characterization of lactobacilli isolated from artisanal meat plants and traditional fermented sausages of Veneto region. Lett. Appl. Microbiol. 2001, 33, 26-30. [CrossRef] [PubMed]

27. Papamanoli, E.; Tzanetakis, N.; Litopoulou-Tzanetaki, E.; Kotzekidou, P. Characterization of lactic acid bacteria isolated from a Greek dry-fermented sausage in respect of their technological and probiotic properties. Meat Sci. 2003, 65, 859-867. [CrossRef]

28. Leroy, F.; de Vuyst, L. Temperature and $\mathrm{pH}$ Conditions That Prevail during Fermentation of Sausages Are Optimal for Production of the Antilisterial Bacteriocin Sakacin K. Appl. Environ. Microbiol. 1999, 65, 974-981. [CrossRef] [PubMed]

29. Leroy, F.; de Vuyst, L. The Presence of Salt and a Curing Agent Reduces Bacteriocin Production byLactobacillus sakei CTC 494, a Potential Starter Culture for Sausage Fermentation. Appl. Environ. Microbiol. 1999, 65, 5350-5356. [CrossRef]

30. Martin, B.; Garriga, M.; Hugas, M.; Bover-Cid, S.; Veciana-Nogués, M.T.; Aymerich, T. Molecular, technological and safety characterization of Gram-positive catalase-positive cocci from slightly fermented sausages. Int. J. Food Microbiol. 2006, 107, 148-158. [CrossRef]

31. Ravyts, F.; Steen, L.; Goemaere, O.; Paelinck, H.; De Vuyst, L.; Leroy, F. The application of staphylococci with flavour-generating potential is affected by acidification in fermented dry sausages. Food Microbiol. 2010, 27, 945-954. [CrossRef]

32. Fista, G.A.; Bloukas, J.G.; Siomos, A.S. Effect of leek and onion processing and quality characteristics of Greek traditional sausages. Meat Sci. 2004, 68, 163-172. [CrossRef]

33. Iacumin, L.; Comi, G.; Cantoni, C.; Cocolin, L. Molecular and technological characterization of Staphylococcus xylosus isolated from naturally fermented Italian sausages by RAPD, Rep-PCR and Sau-PCR analysis. Meat Sci. 2006, 74, 281-288. [CrossRef]

34. Morot-Bizot, S.; Talon, R.; Leroy-Setrin, S. Development of specific PCR primers for a rapid and accurate identification of Staphylococcus xylosus, a species used in food fermentation. J. Microbiol. Methods 2003, 55, 279-286. [CrossRef] 
35. Verluyten, J.; Leroy, F.; Vuyst, L. Effects of Different Spices Used in Production of Fermented Sausages on Growth of and Curvacin A Production by Lactobacillus curvatus LTH 1174. Appl. Environ. Microbiol. 2004, 70, 4807-4813. [CrossRef] [PubMed]

36. Mu, C.; Bian, G.; Su, Y.; Zhu, W. Differential Effects of Breed and Nursing on Early-Life Colonic Microbiota and Immune Status as Revealed in a Cross- Fostering Piglet. Appl. Environ. Microbiol. 2019, 85, e02510-e02518. [CrossRef] [PubMed]

37. Yang, H.; Huang, X.; Fang, S.; Xin, W.; Huang, L.; Chen, C. Uncovering the composition of microbial community structure and metagenomics among three gut locations in pigs with distinct fatness. Sci. Rep. 2016, 6, 27427. [CrossRef] [PubMed]

38. Tan, Z.; Yang, T.; Wang, Y.; Xing, K.; Zhang, F.; Zhao, X.; Ao, H.; Chen, S.; Liu, J.; Wanet, C. Metagenomic analysis of cecal microbiome identified microbiota and functional capacities associated with feed efficiency in landrace finishing pigs. Front. Microbiol. 2017, 8, 1546. [CrossRef] [PubMed]

39. Bian, G.R.; Ma, S.Q.; Zhu, Z.G.; Su, Y.; Zoetendal, E.G.; Mackie, R.; Liu, J.H.; Mu, C.L.; Huang, R.H.; Smidt, H.; et al. Age, introduction of solid feed and weaning are more important determinants of gut bacterial succession in piglets than breed and nursing mother as revealed by a reciprocal cross-fostering model. Environ. Microbiol. 2016, 18, 1566-1577. [CrossRef] [PubMed]

40. Monin, G.; Mejenes-Quijano, A.; Talmant, A.; Sellier, P. Influence of breed and muscle metabolic type on muscle glycolytic potential and meat $\mathrm{pH}$ in pigs. Meat Sci. 1987, 20, 149-158. [CrossRef]

41. Zentek, J.; Ferrara, F.; Pieper, R.; Tedin, L.; Meyer, W.; Vahjen, W. Effects of dietary combinations of organic acids and medium chain fatty acids on the gastrointestinal microbial ecology and bacterial metabolites in the digestive tract of weaning piglets. J. Anim. Sci. 2013, 91, 3200-3210. [CrossRef]

42. Nguyen, D.H.; Lee, K.Y.; Tran, H.N.; Kim, I.H. Effect of a protected blend of organic acids and medium-chain fatty acids on growth performance, nutrient digestibility, blood profiles, meat quality, faecal microflora, and faecal gas emission in finishing pigs. Can. J. Anim. Sci. 2019, 99, 448-455. [CrossRef]

43. Albrecht, A.; Hebel, M.; Mittler, M.; Hurck, C.; Kustwan, K.; Heitkonig, B.; Bitschinski, D.; Kreyenschmidt, J. Influence of Different Production Systems on the Quality and Shelf Life of Poultry Meat: A Case Study in the German Sector. J. Food Qual. 2019, 3718057. [CrossRef]

44. Gounadaki, A.S.; Skandamis, P.N. Microbial ecology of food contact surfaces and products of small-scale facilities producing traditional sausages. Food Microbiol. 2008, 25, 313-323. [CrossRef] [PubMed]

45. Duffy, E.A.; Belk, K.E.; Sofos, J.N.; Bellinger, G.R.; Pape, A.; Smith, G.C. Extent of Microbial Contamination in United States Pork Retail Products. J. Food Prot. 2001, 64, 172-178. [CrossRef]

46. Saide-Albornoz, J.J.; Knipe, C.L.; Murano, E.A.; Beran, G.W. Contamination of Pork Carcasses during Slaughter, Fabrication, and Chilled Storage. J. Food Prot. 1995, 58, 993-997. [CrossRef] [PubMed]

47. Altschul, S.F.; Madden, T.L.; Shaffer, A.A.; Zhang, J.; Zhang, Z.; Miller, W.; Lipman, D.J. Gapped BLAST and PSI-BLAST: A new generation of protein database search programs. Nucleic Acids Res. 1997, 25, 3389-3402. [CrossRef] [PubMed]

48. White, H. Asymptotic Theory for Econometricians; Academic Press: Orlando, FL, USA, 1980.

49. Dytham, C. Choosing and Using Statistics: A Biologist's Guide, 2nd ed.; Blackwell: Malden, MA, USA, 2003.

50. Vauterin, L.; Vauterin, P. Computer-aided objective comparison of electrophoretic patterns for grouping and identification of microorganisms. Eur. Microbiol. 1992, 1, 37-41.

51. Ammor, S.; Rachman, C.; Chaillou, S.; PreÅLvost, H.; Dousset, X.; Zagorec, M.; Dufour, E.; Chevallier, I. Phenotypic and genotypic identification of lactic acid bacteria isolated from a small-scale facility producing traditional dry sausages. Food Microbiol. 2005, 22, 373-382. [CrossRef]

52. Comi, G.; Urso, R.; Iacumin, L.; Rantsiou, K.; Cattaneo, P.; Cantoni, C.; Cocolin, L. Characterization of naturally fermented sausages produced in North East of Italy. Meat Sci. 2005, 69, 381-392. [CrossRef]

53. Greco, M.; Mazette, R.; De Santis, E.P.L.; Corona, A.; Cosseddu, A.M. Evolution and identification of lactic acid bacteria isolated during the ripening of Sardinian sausages. Meat Sci. 2005, 69, 733-739. [CrossRef]

54. Talon, R.; Leroy, S.; Lebert, I. Microbial ecosystems of traditional fermented meat products: The importance of indigenous starters. Meat Sci. 2007, 77, 55-62. [CrossRef]

55. Casaburi, A.; Aristoy, M.C.; Cavella, S.; Di Monaco, S.; Di Monaco, R.; Ercolini, D.; Toldra, F.; Villani, F. Biochemical and sensory characteristics of traditional fermented sausage of Vallo di Diano (Southern Italy) as affected by the use of starter cultures. Meat Sci. 2006, 76, 295-307. [CrossRef] 
56. Kostinek, M.; Specht, I.; Edward, V.A.; Schillinger, U.; Hertel, C.; Holzapfel, W.H.; Franz, C.M. Diversity and technological proprities of predominant lactic acid bacteria from fermented cassava used for the preparation of Gari, a traditional African food. Syst. Appl. Microbiol. 2005, 6, 527-540. [CrossRef] [PubMed]

57. Torriani, S.; Di Bucchianico, R.; Pattarini, F.; Zabeo, G.; Dell'Aglio, F. Presence and biotechnological charaterization of lactic acid bacteria and micrococcaceaea strains in Abruzzo traditional raw dry sausages. Ind. Delle Conserve 1994, 69, 3-9.

58. Villani, F.; Casaburi, A.; Pennacchia, C. Microbial ecology of the soppressata of Vallo di Diano, a traditional dry fermented sausage from southern Italy, and in vitro and in situ selection of autochthonous starter cultures. Appl. Environ. Microbiol. 2007, 73, 5453-5463. [CrossRef] [PubMed]

59. Mosquera, C.; Donoso, E.; Valenzuela, Y.M.; Arizaga, R.; Salous, A.E. Effect of probiotic and prebiotic in the formulation and elaboration of sausage as an alternative of consumption. Int. J. Res. Pharm. Sci. 2019, 10, 2781-2785. [CrossRef]

60. Sidira, M.; Mitropoulou, G.; Galanis, A.; Kanellaki, M.; Kourkoutas, Y. Effect of sugar content on quality characteristics and shelf-life of probiotic dry-fermented sausages produced by free or immobilized Lactobacillus casei ATCC 393. Foods 2019, 8, 219. [CrossRef]

61. Mehmeti, I.; Muji, S.; Diep, D.B.; Nesa, I.F. High frequency of the potential pathogen Lactococcus garvieae in raw milk from Kosovo. Food Control. 2015, 53, 189-194. [CrossRef]

62. Beck, R.; Weiss, N.; Winter, J. Lactobacillus graminis sp. nov., a New Species of Facultatively Heterofermentative Lactobacilli Surviving at Low pH in Grass Silage. Syst. Appl. Microbiol. 1988, 10, 279-283. [CrossRef]

63. Lebert, I.; Leroy, S.; Giammarinaro, P.; Lebert, A.; Charcornac, J.P.; Bover-Cid, S.; Vidal-Carou, M.C.; Talon, R. Diversity of microorganisms in the environment and dry fermented sausages of small traditional French processing units. Meat Sci. 2007, 76, 112-122. [CrossRef]

(C) 2020 by the authors. Licensee MDPI, Basel, Switzerland. This article is an open access article distributed under the terms and conditions of the Creative Commons Attribution (CC BY) license (http://creativecommons.org/licenses/by/4.0/). 